\title{
Examination of Household Solid Waste Management in Nadowli Township in Ghana: A Waste Management Hierarchy Approach
}

\author{
Francis Issahaku Malongza Bukari \\ Department of Environment and Resource Studies, University \\ for Development Studies, Wa Campus, Ghana \\ malongza@outlook.com \\ Dzigbodi Adzo Doke \\ Department of Environment and Resource Studies, University \\ for Development Studies, Wa Campus, Ghana \\ Stephen Bugu Kendie \\ Institute for Development Studies, College of Humanities and Legal \\ Studies, University of Cape Coast, Cape Coast, Ghana

\section{Nana Amma Anokye} \\ Faculty of Social and Humanities, London Metropolitan University, United Kingdom \\ DOI//http://dx.doi.org/10.4314/gjds.v14i2.10
}

\begin{abstract}
The purpose of the study was to identify the gaps between existing practices and the provisions of the hierarchy of waste management model in the Nadowli Township of the Upper West Region of Ghana. A cross-sectional study design with quantitative and qualitative approaches was adopted and questionnaires, observation and interview guides were used to collect data from a sample size of 100 respondents. Findings revealed that the methods of waste management in the model cannot be practiced without linkage to the roles of stakeholders. While waste disposal is the least preferred option in theory, it was the most practiced method. Accordingly, avoidance, reduction, reuse and recycling were less practiced, resulting in ineffective prevention of pollution, diseases, environmental resource conservation and sustainability. It was recommended that adequate coverage of educational campaigns and infrastructural development could bridge the gap between theory and practice.
\end{abstract}

Keywords: Solid Waste, Waste Management Methods, Stakeholders, Nadowli 


\section{Introduction}

Household solid waste refers to discarded items that are no longer useful to households (Vergara \& Tchobanoglous, 2012). Households generate waste through sweeping of compounds, food processing and consumption, building and construction, replacement and disposal of worn-out utensils, furniture, appliances and clothing. These result in food wastes, paper, metal, wood, textile, plastic and glass wastes (Gettis, Gettis \& Fellmann, 2006).

Also, liquid waste generation must be contended with. However, Solid waste is of major environmental concern because it is uneasy to degenerate (Tonjes \& Greene, 2013). It is usually unsightly, smelly, toxic and capable of polluting land, air and water sources (Toxics Action Center, 2012). Diarrhoea, dysentery, typhoid, intestinal parasites and cholera are some of the diseases acquired to improper solid waste management (Environmental Protection Agency - Ghana, 2003).

In towns and cities, high population amplifies household solid waste generation (Chukwudi \& Oluwafemi, 2014) hence, the institutional arrangements for waste management methods are often more organised and advanced. Households, private sector organisations and the public sector constitute the stakeholders in household solid waste management (van de Klundert \& Anschiitz, 200o). These employ methods that are often described in a hierarchical order, known as the waste management hierarchy (Picket, 2010). The methods include avoidance, reduction, reuse, recycling, energy recovery and disposal (Ewijk \& Stegemann, 2014). Other roles indirectly linked to waste management methods include support and coordination of services by donors, advocacy and campaign for better services by the Civil Society (The Civil Society Organisations Communique, 2011), and policy and funding by the public sector. Formal service delivery is usually by public-private partnership. Households practise the waste management methods domestically and owe positive service use behaviour to the public-private sector.

Nadowli is the capital of the Nadowli-Kaleo District of the Upper West Region and an urbanising area with a population of about 4,085 (Ghana Statistical Service, 2014). Although its population falls short of the requirement for an urban town in Ghana as per the classification of the Ghana Statistical Service (5000 or more), its status as a district capital makes it assume urban features. These include administrative roles, heterogeneity of society due to the presence of diverse people, and existence of professionalism in occupations beyond peasant agriculture (Mondal, 2015).

Despite the involvement of the Community Water and Sanitation Agency (CWSA) and a limited liability company of Ghanaian origin, called Zoomlion Ghana Ltd. contracted to 
manage waste in the district, $41 \%$ of households still practise indiscriminate dumping of waste, while another $41 \%$ use open dump sites. Only $2.4 \%$ of households subscribe to the available house-to-house waste collection services (Ghana Statistical Service [GSS], 2014). These expose residents to diseases due to environmental pollution. National census survey data are limited in their space-specific policy implications, and lack adequate information on the roles of the various stakeholders and the effectiveness of their activities in waste management with reference to standards.

Ghana's decentralisation programme implemented in 1988 devolves waste management responsibilities to the District Assemblies (DAs). To support this, a DAs Common Fund was established to which not less than $5 \%$ of national (internal) revenue is distributed to the DAs according to a formula determined by parliament, apart from other sources of income for the DAs, to support their development work, including waste management.

Towns grow, not only by manufacturing activity but also administrative and market functions. The creation of a district capital brings with it new offices for decentralised state institutions. This stimulates migration as staff would be needed for the new offices, leading to a multiplier effect as derived demand for housing, transportation and other ancillary services, and Nadowli is no exception to this scenario.

Research links the wealth of a city and its waste management situation. For instance, Kendie (1999) asserts that wealthy cities are able to fund waste management and enforce rules against insanitary behaviours, whereas in poor cities, pressing problems of education, health care and water supply result in very limited funds for waste management. Following the adoption of neo-liberal economic policies, Ghana entered into public-private partnerships for waste management. The private company Zoomlion, is present in all large communities in Ghana. However, scarcity of funds impedes its efficiency, making the challenges of waste management persistent.

Literature on waste management in Ghana has largely focused on the major cities of Accra, Kumasi, Tamale, Cape Coast and so on. These are also the centres with better health facilities to deal with disease outbreaks. The roles of rural towns such as Nadowli, acting as sponges to reduce migration to the cities need no further emphasis. Creating conducive environments in such small towns to provide services to the rural communities is both a political and economic strategy that could help reduce the inmigration problems the cities face. Therefore, understanding the specific roles and complementarities of stakeholders would help to vitalise these small towns for socioeconomic development. This paper therefore describes the state of household solid waste management in the Nadowli Township, using the waste management hierarchy model as the theoretical lens. The overarching research question addressed by this study is: How is household solid waste managed in Nadowli? 


\section{Conceptual Issues}

This section presents the abstraction of theoretical antecedents, concepts, variables and interrelated ideas that shape the focus of the study. It shows the methods stipulated in the hierarchy of waste management model by Ad Lansink in Dutch Parliament in 1979 (Ewijk \& Stegemann, 2014). Preferentially, these include avoidance, reduction, reuse, recycling, energy recovery and disposal of waste (Zeng, Sun, Huo, Wan \& Jing, 2010). Figure 1 indicates the stakeholders in waste management and those whose roles relate to the practice of the waste management methods, namely the public and private sectors and households.

The top left side of Figure 1, indicates that support and coordination by donors, as well as advocacy, participatory planning and campaign by the civil society, influence the activities of the public and private sectors and households, but are not directly linked to the methods of waste management and so are considered as secondary stakeholders (Anokye, 2013; Civil Society Organisations Communique, 2011; Walker, Viaro \& Wolf, 1999). Examples of donors are the United Nations Center for Regional Development and the United Nations Human Settlements Programme (UN Habitat), and examples of the civil society are the Cooperative for Assistance and Relief Everywhere (CARE) International, Kasa Initiative, WaterAid Ghana and Water and Sanitation for the Urban Poor (WSUP). The public and private sectors and households are shown to have direct link with the household solid waste management methods, and so considered as primary stakeholders.

In Ghana, public sector stakeholders in waste management include the Ministry of Water and Sanitation, under which the CWSA falls, and the Ministry of Local Government and Rural Development to which the Metropolitan, Municipal and District Assemblies belong. These formulate policies, provide funding and render sanitation services (Government of Ghana, 2010). There are also District Water and Sanitation Teams (DWSTs) and District Environmental Health Departments, responsible for the day-to-day water, sanitation and hygiene management. These are assisted by the CWSA at the regional levels and the various Assemblies in terms of the provision of public facilities as well as the use of innovative strategies through partnership with the private sector (WaterAid Ghana, 2005; Kumasi Metropolitan Assembly, 2015). The Ministry of Environment, Science and Technology (MEST) also participates in sector-wide approach for effective coordination of sanitation and associated services delivery (MEST, 2012). The private sector ranks next after the public sector. In Ghana, Zoomlion Ghana Ltd. is a dominant private limited liability company which works through public-private-partnership for household and community waste management as well as private sector customers. 


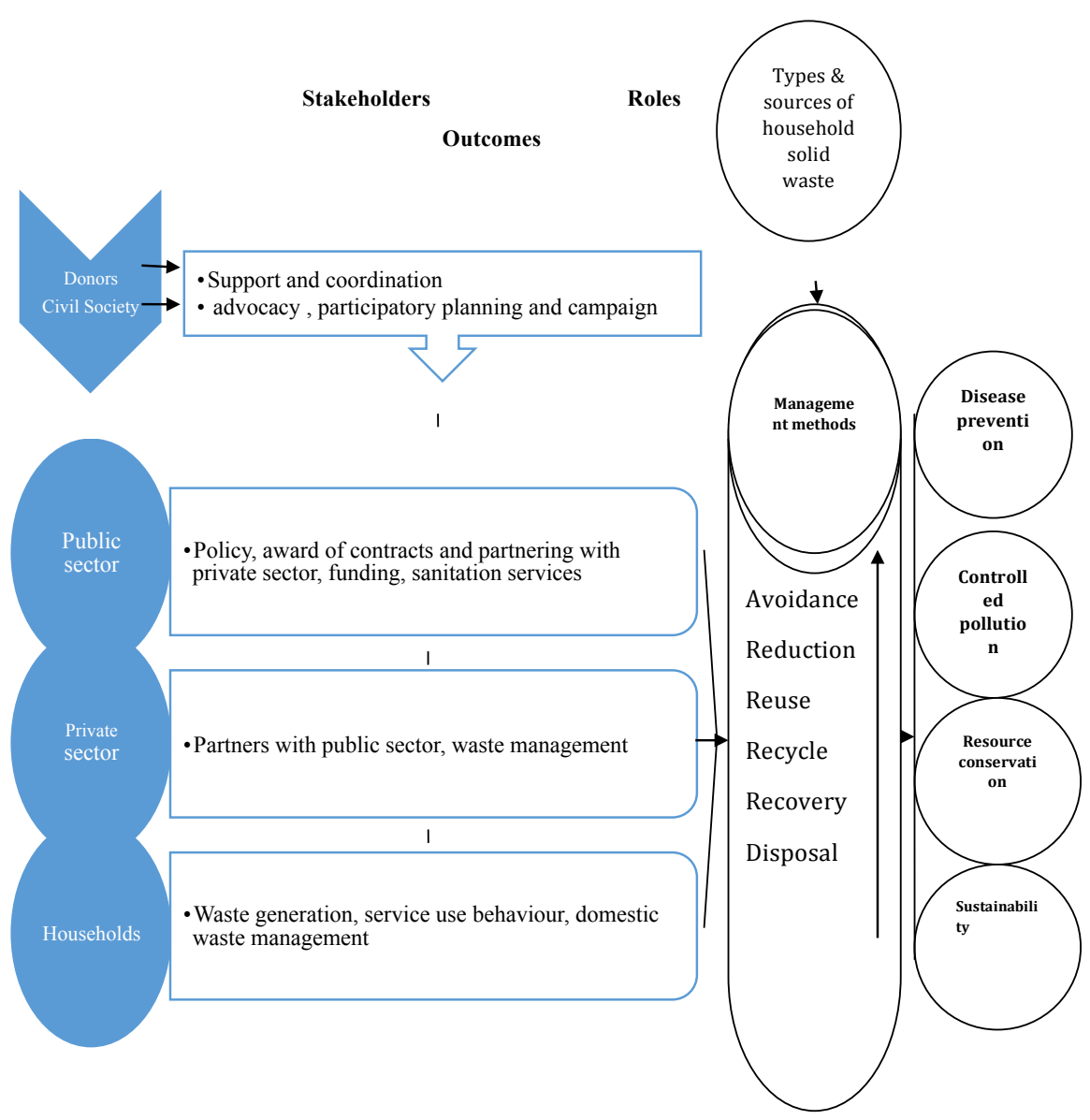

Figure 1: Framework of household solid waste management : ascending order.

Based on Stegemann (2014)

Linking the stakeholders to the methods of waste management in the hierarchy, avoidance, reduction and reuse are behavioral practices associated with households, while sanitation services of the public and private sectors influence such behaviours through public education and motivation (Janmaimool, 2017). Recycling and energy recovery are also practicable domestically by households, while the public and private sectors could apply more advanced methods of doing these together with waste disposal. The private sector executes the waste management methods according to contracts with the public sector or households in communities (Baud, Post \& Furedy, 2004). 
When households avoid waste generation, unhealthy environment and the associated cost of waste management are eliminated. Households could also minimise waste by the choice of waste reduction consumables as the next best option. This is followed by the reuse of disposable materials after initial use. Damaged textbooks could also be recycled into paper for exercise books or printing paper by public or private sector companies. If there remains any waste after reduction, reuse and recycling, energy recovery, involving the retrieval of energy stored in the waste for other purposes is the next option. Such an instance is using farm waste for biogas and generating electricity through the combustion of other wastes in furnaces (Randell, 2012). These leave some residue, which if treated and safely disposed as the least preferred option, could also influence environmental sustainability.

The framework explains that cooperation between the stakeholders could lead to some positive outcomes, including controlled environmental pollution and disease prevention as solid waste is avoided or reduced (UN Water, 2008). Furthermore, reuse, recycling and recovery minimise extraction of environmental resources for new products to meet increasing demand, leading to resource conservation and environmental sustainability, by enabling present and future generations to meet their needs (Getis, Getis \& Fellman, 2006).

The significance of this conceptual framework is that it serves as an improvement of Ad Lansink's hierarchy of waste management model, since the methods are impracticable without stakeholder activities, which should yield outcomes. Even though this still undermines other stages of waste management, such as collection, storage and transportation, it provides a guide for a systematic assessment of household solid waste management, by comparing existing practices to what the model suggests.

\section{Methodology}

The study design was cross-sectional. This began with a community walk to facilitate the identification of populous zones of the Nadowli Township with evidence of solid waste generation and management. This resulted in the purposeful selection of four zones of the town, namely Yipaala, Ganga, Nawule and Sorikuo for the study. In each zone, a cross-section was demarcated and houses therein enumerated and coded.

Taro's formula was used to calculate the sample size for household respondents (See Yamene, 1967). This yielded 97.61, rounded off to 100, based on a population of 4,085 at 0.1 or $10 \%$ confidence level. There were a total of 115 houses for the selected crosssections of the zones, from which 100 were selected by the fish-bowl method. The actual sample units were households, and a respondent who was 18 years and above was selected accidentally from a house, and all members of his/her household could 
participate in the interview. There were also four organisational respondents, including one official each from the District Water and Sanitation Team, Zoomlion Ghana Ltd., the District Environmental Health Department and Nadowli Hospital, to whom semistructured questionnaires were administered.

Both quantitative and qualitative approaches were adopted. The quantitative approach related to the positivist worldview. The data from households were presented using frequency tables and charts, and analysed by establishing meaning, understanding and identifying the relationships between variables and concepts in the contexts of the research objectives and the conceptual framework. The qualitative approach related to the critical theory paradigm, involving inquiries into the weaknesses of the existing household solid waste management situation and the effects on households, and finding out ways of addressing the identified gaps. Qualitative data was obtained from the organisational respondents and related literature, and analysed by narrations and descriptions using words, concurrently with quantitative analysis.

\section{Results and Discussion}

The results were presented and discussed according to the steps in the waste management model. The specific aspects of household solid waste management related to the types and sources of waste, stakeholders, ascending order of methods used and the outcomes.

\section{Types and Sources of Household Solid Waste}

Table 1 reveals respondents' observations of the types and sources of solid waste. It indicates that when compounds are swept, pieces of paper, food, bottles, polythene bags, sachets of used products and domestic animal droppings are brought together as yard waste (See also Vergara \& Tchobanoglous, 2012). This represents the highest response of 50\%. Disposal of worn-out clothing and leather materials constitute the next highest source of household solid waste, with $18 \%$ of the responses. These constitute textile waste and leather waste respectively. These together with yard waste are a significant source of household waste because they are generated from essential components of household basic needs (Palm, 2011).

Disposal of damaged and unwanted household utensils such as kitchen kits, made of metal, plastic and wooden materials constitute the third ranking source and types of household solid waste, with $10 \%$ of the responses. These are followed by disposed wornout metallic, plastic and wooden household appliances, such as radios, televisions and refrigerators, bulbs, ceiling and standing fans among others, constituting $9 \%$ of the 
responses, while the remaining $5 \%$ recognised the disposal of household furniture, made of wood and metal.

Table 1: Household solid wastes

\begin{tabular}{|l|l|l|}
\hline Type of household solid waste & Main source & $\begin{array}{l}\text { Percentage of } \\
\text { respondents } \\
\text { recognising the type } \\
\text { and sources }\end{array}$ \\
\hline $\begin{array}{l}\text { Yard waste including paper, sachets, } \\
\text { polythene bags, bottles, animal } \\
\text { droppings }\end{array}$ & $\begin{array}{l}\text { Package disposal and intensive } \\
\text { livestock rearing }\end{array}$ & 50 \\
\hline $\begin{array}{l}\text { Scrap concrete, metals, glass and } \\
\text { wood wastes }\end{array}$ & $\begin{array}{l}\text { Construction and reconstruction of } \\
\text { domestic buildings }\end{array}$ & 8 \\
\hline $\begin{array}{l}\text { Worn-out metallic, plastic, clayey and } \\
\text { wooden utensils }\end{array}$ & Disposal of household utensils & 10 \\
\hline $\begin{array}{l}\text { Worn-out metallic, wooden and } \\
\text { plastic appliances }\end{array}$ & Disposal of household appliances & 9 \\
\hline $\begin{array}{l}\text { Worn-out wooden and metallic } \\
\text { furniture }\end{array}$ & Disposal of household furniture & 5 \\
\hline Textile and leather wastes & Disposal of worn - out clothing & 18 \\
\hline & Total & $\mathbf{1 0 0}$ \\
\hline
\end{tabular}

Source: Field data, 2015

The pattern of responses reveals that less durable products rank higher among the types of solid wastes and vice versa. It was estimated that about $120 \mathrm{~m}^{3}$ of waste is generated per month, but only $4 \mathrm{Om}^{3}$ is collected and disposed in Nadowli Township. In other words, as a district capital with a population of 4,085 , about seven public waste containers, each worth $6 \mathrm{~m}^{3}$ by volume are emptied at the Nadowli landfill site monthly (Interview with Zoomlion officials, July 2015). This implies that about two-thirds of residents of Nadowli do not patronise the public waste container services.

The inquiry was also extended into the anthropogenic activities of households linked to the types of solid wastes, such as occupation and the types of industry. Table 2 reveals that the largest employer of household labour is the agro-based industry with $75.5 \%$, followed by the wood-based industry with $11.5 \%$. Other industries in a descending order include textile-based, sand and clay-based, and metallic-based industries. 
Table 2: Solid waste related industrial activities of households

\begin{tabular}{|l|l|l|l|}
\hline Type of industry & Typical activities & $\begin{array}{l}\text { Percentage } \\
\text { Share of the } \\
\text { industry in } \\
\text { the district }\end{array}$ & $\begin{array}{l}\text { Percentage of } \\
\text { respondents } \\
\text { involved }\end{array}$ \\
\hline Agro-based & $\begin{array}{l}\text { Milling, pito brewery, chop bars, } \\
\text { shea butter processing }\end{array}$ & $75 \cdot 5$ & 66 \\
\hline Wood - based & $\begin{array}{l}\text { Carpentry, carving, weaving, } \\
\text { charcoal burning }\end{array}$ & 11.5 & 14 \\
\hline Textile-based & Tailoring, smock weaving & 7.4 & 9 \\
\hline Sand and clay-based & $\begin{array}{l}\text { Sand winning, pottery, block } \\
\text { making, masonry, road } \\
\text { construction }\end{array}$ & 3.6 & 8 \\
\hline Metal-based & $\begin{array}{l}\text { Blacksmithing, mechanical } \\
\text { repairers }\end{array}$ & $\mathbf{2 . 0}$ & 3 \\
\hline Total & $\mathbf{1 0 0}$ & $\mathbf{1 0 0}$ \\
\hline
\end{tabular}

Source: Field data, 2015; Ghana Statistical Service (2014)

The data in the first column of Table 2 (types of industry) have a clear relationship with that in the first column of Table 1(types of household solid waste). It is also obvious that the prevalence of the activity level of each industry, indicated by the percentage of people involved in it (see fourth column of Table 2), corresponds to the ranking of the types and sources of solid wastes in the third column of Table 1. This confirms that occupational activities of households influence the types and sources of waste generated. It also means that largest volumes of waste come from those activities that the greatest proportions of the population engage in.

The dominant type of solid waste depicts the dominant economic sector; whether primary, secondary/manufacturing or tertiary (in ascending order). This study reveals primary sector dominance, specifically agrarian. This is not surprising for a district capital in a developing country with a population that could not be described as urban.

\section{Stakeholders in Household Solid Waste Management}

As suggested by the conceptual framework, it was considered appropriate to identify the stakeholders and the methods used. The findings show that Zoomlion Ghana Ltd., which is a private sector organisation, had the highest recognition of $60 \%$ among the respondents. It was followed by the District Water and Sanitation Team with $15 \%$, while the District Environmental Health Department was also recognised by $2 \%$ of the respondents. These two are public sector organisations in the area of sanitation in the community. The community Committees had $7 \%$, while households were least recognised by $6 \%$. 
Stakeholders

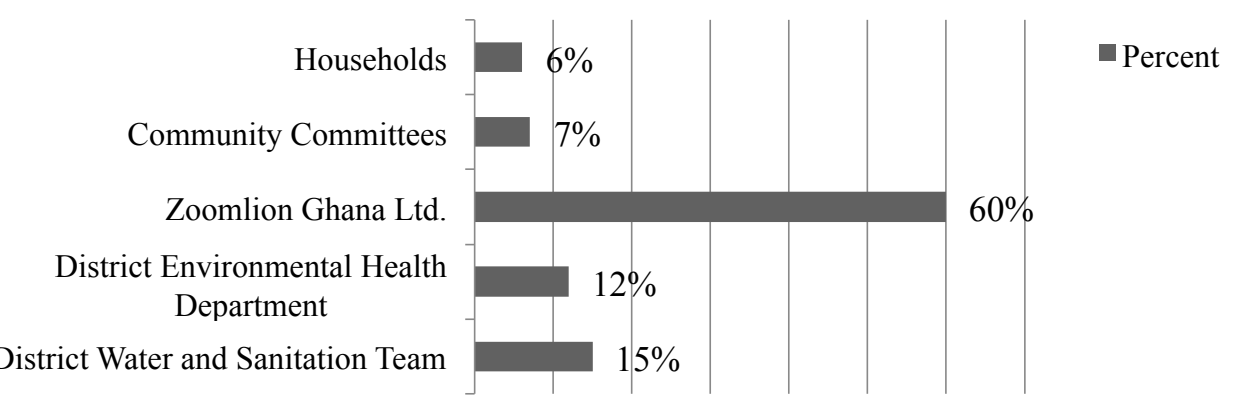

Figure 2: Stakeholders in household solid waste management

Source: Field data, 2015

The higher recognition of Zoomlion Ghana Ltd. as the active stakeholder above other primary stakeholders confirms its dominance in household waste management. Interview with the Upper West Regional Manager of the company revealed that it is contracted to manage waste by the Metropolitan, Municipal and District Assemblies as local government bodies. He added that these bodies define what work is to be done at specified locations. The company provides all the logistics as the contractor, while the Assemblies provide funding using the District Assembly Common Fund (See also Kendie, 1999).

It was revealed that effective execution of the waste management contracts is often challenged by delayed funding. The manager pointed out that the contracts are awarded and paid for on quarterly basis. However, delayed payment by the Assemblies impedes smooth operations, since payment of menial labour, fuelling, repair and maintenance of compaction trucks and tricycles, as well as other managerial logistics are negatively affected. These result in gluts of waste in the surroundings, dump sites and landfills of urbanised areas assigned to the company.

Interview with officials of District Assembly also confirmed the late disbursement of the Common Fund. For instance in 2016, the Nadowli-Kaleo District Assembly composite budget proposed a total expenditure of $\mathrm{GH}_{201}, 079$ for the promotion of sanitation, hygiene and health. However, there were no funding in-flows to make implementation possible (Nadowli-Kaleo District Assembly, 2016).

In Figure 2, households ranked low because they are considered as waste generators and not being involved in the formal decision making processes and activities in waste 
management. This is consistent with the findings of Snel and Ali (1999), who ranked local community level structures low among stakeholders in waste management, while van de Klundert and Scheinberg (2001) did not identify households as stakeholders on their list. However, interview with Zoomlion official indicated that households have the responsibilities of cleaning their homes and paying directly for house-to-house waste

collection services rendered by the company. This is an aspect of service use behaviour as stipulated in the conceptual framework (Figure 1).

Interviews with officials of the District Water and Sanitation Team and the District Environmental Health Department at Nadowli revealed the roles of the District Assembly and the CWSA as stakeholders of the public sector, the United Nations Children's Fund (UNICEF) as a donor, and Maallu Foundation for Rural Development (MAFORD) and First Priority Club as civil society organisations. The District Water and Sanitation Team as a wing of the District Assembly is a three-member team comprising an Engineer, a hygiene expert and a community mobiliser. It provides technical assistance to the Community Water and Sanitation Committees and oversees the general management of water and sanitation services in the district (see also Komives, Akanbang, Thorsten, Tuffuor, Wakeman, Wasser, Larbi, Bakalian \& Whittington, 2008). UNICEF and the MAFORD support the Community-Led Total Sanitation and Integrated Hand Washing with Soap programmes. First Priority Club is a non-governmental organisation, which organises clean-up campaigns for improved sanitation in the community. The next section examines the roles of the stakeholders in the practice of the methods of management.

\section{Methods of Household Solid Waste Management}

The presentation and analysis of results in this section follow the methods specified in the conceptual framework (Figure 1) in ascending order. These represent the basic elements of the hierarchy of waste management, while identifying the differences between the theoretical provisions and practices in the study area.

\section{Waste Disposal}

Figure 3 reveals that waste disposal was found to take place at two different levels; household and formal organisational levels. In the former case households collect and store waste in litter bins, ordinary plastic and metal containers, identified by $42 \%$ of the respondents. Another 18\% mentioned the use of empty fertiliser sacks and polythene bags for waste storage.

The use of garbage bins provided by Zoomlion Ghana Ltd. was by $16 \%$ of the hopuseholds. Such bins are obtained through registration with the company, and monthly fees are paid for the associated services. Thus, in most cases, it is the middle and high income 
households that subscribe for the services (van de Klundert \& Anschutz, 2001). Ranked next are those who heap their solid wastes by their compounds, which rated $14 \%$. Those who practice this complain of inadequate community waste containers and the inability to afford the monthly rates associated with the registered garbage bin collection services by Zoomlion Ghana Ltd. The remaining 10\% use privately acquired garbage bins. Figure 3 reveals a weakness in the hierarchy of waste management, as the data show that the storage of waste prior to disposal is a recognised management method, but ignored in the hierarchy.

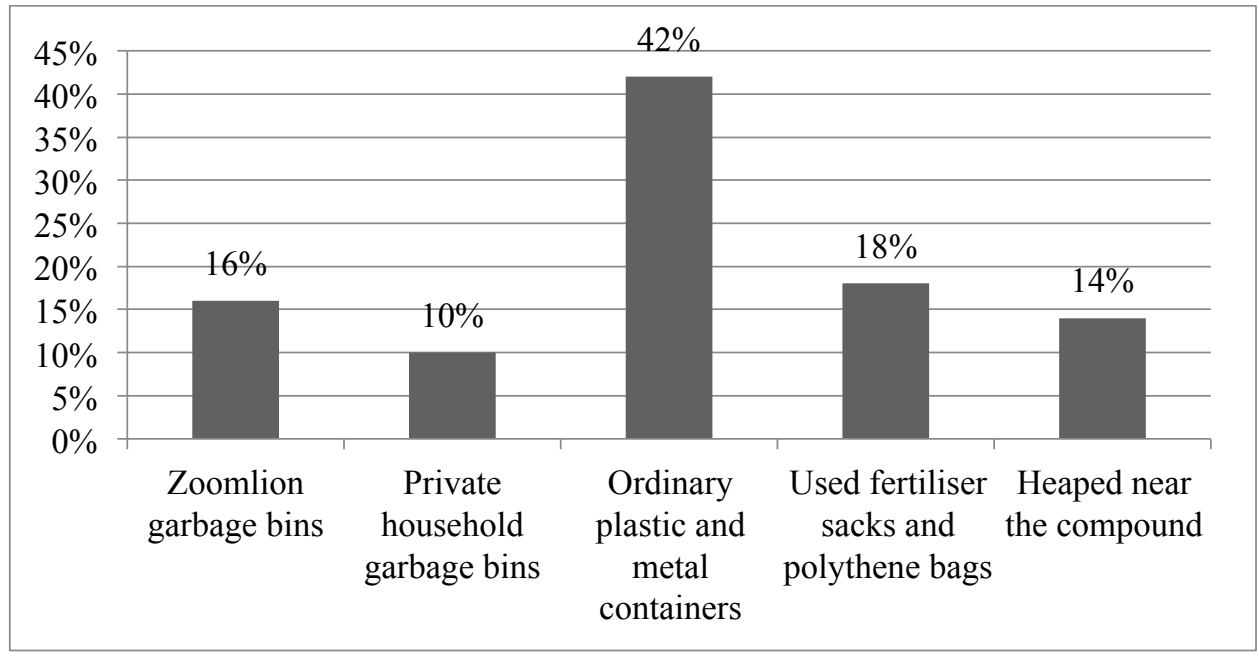

Figure 3: Storage of waste by households before disposal

Source: Field data, 2015

Figure 4 shows that the actual disposal of solid waste by households themselves is popularly by incineration or burning, especially those who heap the wastes on bear ground or in dug pits in their backyards. This constituted $49 \%$ of the responses, followed by depositing of wastes at open dumpsites owned by clusters of houses in the various subsections of the community, constituting $19 \%$ of the responses. 


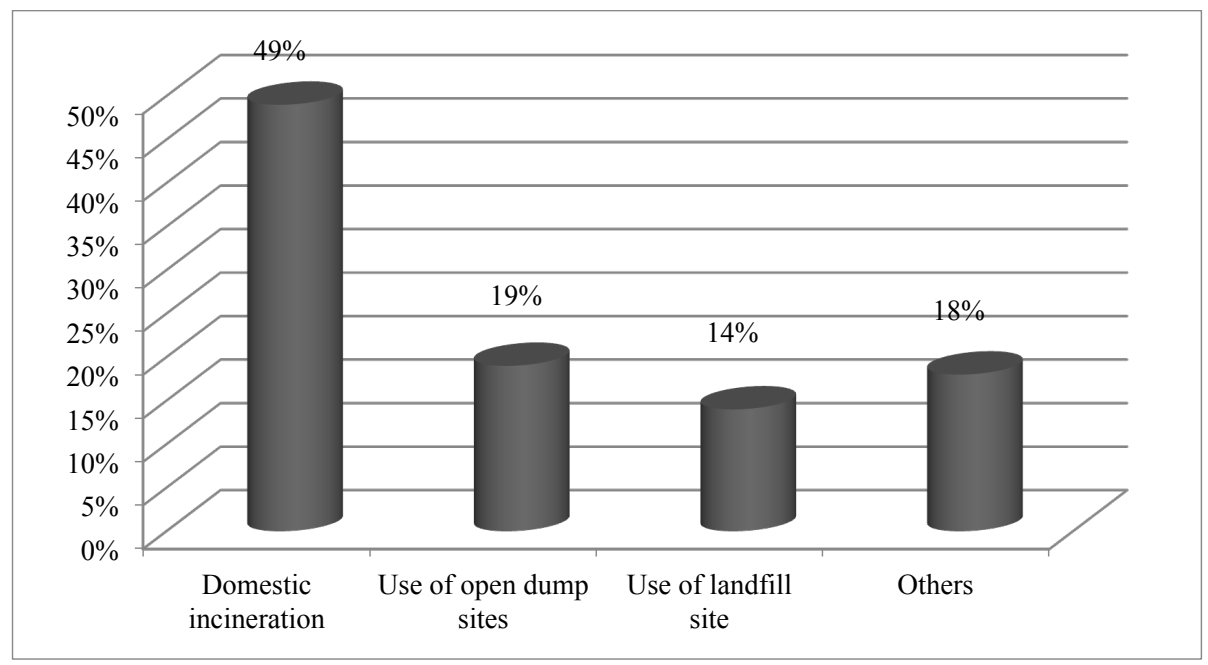

Figure 4: Methods of household solid waste disposal

Source: Field data, 2015

Observation of typical open dumpsites at Nawule and Sorikuo in Nadowli revealed the various types of household solid waste presented in Table 1 . The sites were generally smelly and unsightly. These negatively impact on the objective of preventing environmental pollution through waste management (Griffin, 2006). Other methods included throwing into open gutters and indiscriminate disposal, especially those who gather and tie up their wastes in polythene bags. This method was used by $18 \%$ of the respondents. The use of open dump sites together with indiscriminate disposal of solid waste prevailed over the use of the formal landfill in the community.

Interview with the District Water and Sanitation Team and the District Environmental Health Department officials in Nadowli, revealed that inadequate waste disposal facilities is a major limitation to institutional efficiency in household solid waste management. With an estimated population of 4,085 and an average household size of six (Ghana Statistical Service, 2014), there are about 681 households in Nadowli. However, there were only 55 household liter bins and seven public waste containers as of June 2015. This implies that only one out of every 12 households had a garbage bin.

Table 3 shows the service charges based on household size and volume of garbage bins used under the services of Zoomlion Ghana Ltd. in Nadowli. Thus, formal sector waste disposal is mainly by Zoomlion Ghana Ltd. This involves emptying the registered garbage bins at the households using tricycles and depositing them at a landfill site located 2 kilometers from the community once every week. 
It was found that households registering for the bins in Nadowli do not request for those above the capacities in Table 3, because increased volumes of garbage bins have higher tariff implications. The volumes of garbage bins observed in this study are however, consistent with those identified by Chukwudi and Oluwafemi (2014), who did not list bin capacities exceeding 240ltrs in a survey of household waste bin and collection methodology in Abuja, Nigeria.

Table 3: Service rates by household size and volume of garbage bin

\begin{tabular}{|l|l|l|l|}
\hline Household size & Garbage bin volume (ltrs) & Quantity & $\begin{array}{l}\text { Collection service rate } \\
\text { (GH } \text { per month) }\end{array}$ \\
\hline $1-5$ & 120 & 1 & 10 \\
\hline $6-10$ & 240 & 1 & 15 \\
\hline $11-15$ & 240 and 120 & $\mathrm{I}, 1$ & 25 \\
\hline $16-20$ & 240 & 2 & 30 \\
\hline $21-25$ & 240 and 120 & 2,1 & 40 \\
\hline Above 25 & 240 & 3 & 45 \\
\hline
\end{tabular}

Source: Interview with Zoomlion official (July, 2015)

Table 3 shows that the monthly rate for a 120ltr bin was GH $\$ 10$, while that of 240ltr bin was GH\$15 as of 2015. The Manager of Zoomlion Ghana Ltd. further explained that while his unit effectively collects the waste from the registered households, majority are not served because the clients feel the services are expensive. This results in widespread unwholesome practices in household solid waste disposal.

On the issue of payment of tariffs, the manager said "most clients have arrears and often complain that the charges are high". According to the Ghana Living Standards Survey Round 6, the monthly household per capita income of rural north Ghana of which Nadowli is part, is about GH $\$ 178.75$ (Ghana Statistical Service, 2014). Households with 12oltr and 240ltr bins therefore spend about 5.6 percent and 8.4 percent of their monthly incomes on waste collection respectively in Nadowli. These exceed the standard expenditure of less than 5 percent of household income on water and sanitation (Adank \& Tuffour, 2013), and explains why only about 2.4 percent of households patronise waste collection services in the Nadowli-Kaleo District as a whole (Ghana Statistical Service, 2014). Thus, while the practise of waste disposal in the findings was consistent with the waste management hierarchy, waste storage and collection were not captured in the model.

\section{Energy Recovery}

Energy recovery from waste appears next on the conceptual framework. Yard wastes have no application in terms of energy recovery in Nadowli. According to the United 
States Environmental Protection Agency (2014), yard waste could be used in the production of landfill gas. Thus, the public-private sector has not provided the technology required for energy recovery, evidenced by the fact that the landfill site in Nadowli is not an engineered one. This contributes to increased volume of yard waste at the landfill.

Wood waste from trees in the neighbourhood and construction works has been identified by all the respondents as being used for charcoal and firewood for domestic fuel. The waste disposed after these recovery processes is ash, which is much reduced in volume, cheaper to manage and of little pollution significance (United States Environmental Protection Agency, 2014).

The use of household wastes, such as scrap metallic, glass, clayey, plastic, textile and leather materials for energy recovery, recorded o\% response. This was confirmed in an interview with the District Water and Sanitation Team and the District Environmental Health Department officials that energy recovery from such wastes has not begun in Nadowli. However, according to the World Bank (1999), these could be used in furnaces to generate heat energy by producing steam, which is converted to kinetic energy in turbines to generate electricity, leaving ash and any unburned materials, which are disposed if no additional uses are found. With the exception of households using wood waste from trees and construction works as domestic fuel, energy recovery as identified in theory, is a gap in practice in Nadowli by the public-private sector.

\section{Waste Recycle}

Figure 5 shows the types of yard waste recyclable by households, basically into compost for backyard farming. The data reveals that ash from burning firewood and charcoal for domestic fuel and food waste were the most recyclable by $30 \%$ and $27 \%$ of households respectively. Others included domestic animal droppings, child faeces and plant leaves and grass from the surroundings. These are gathered through sweeping and deposited in dug pits by some households to decompose. They then spread the decomposed yard waste over their farmlands as compost manure.

Forty percent of the respondents practice composting, while 60\% does not. Apart from the advantages of minimising actual waste disposed, composting is cheaper and has the potential to increase crop yield for poverty reduction among smallholder farmers (Regional Cooperation for Organic Standards and Certification Capacity in East Africa [OSEA], 2015). The low level of compost making by households contributes to higher volumes of disposed waste, hence environmental pollution (Ali, Wang \& Chauhdry, 2016). 


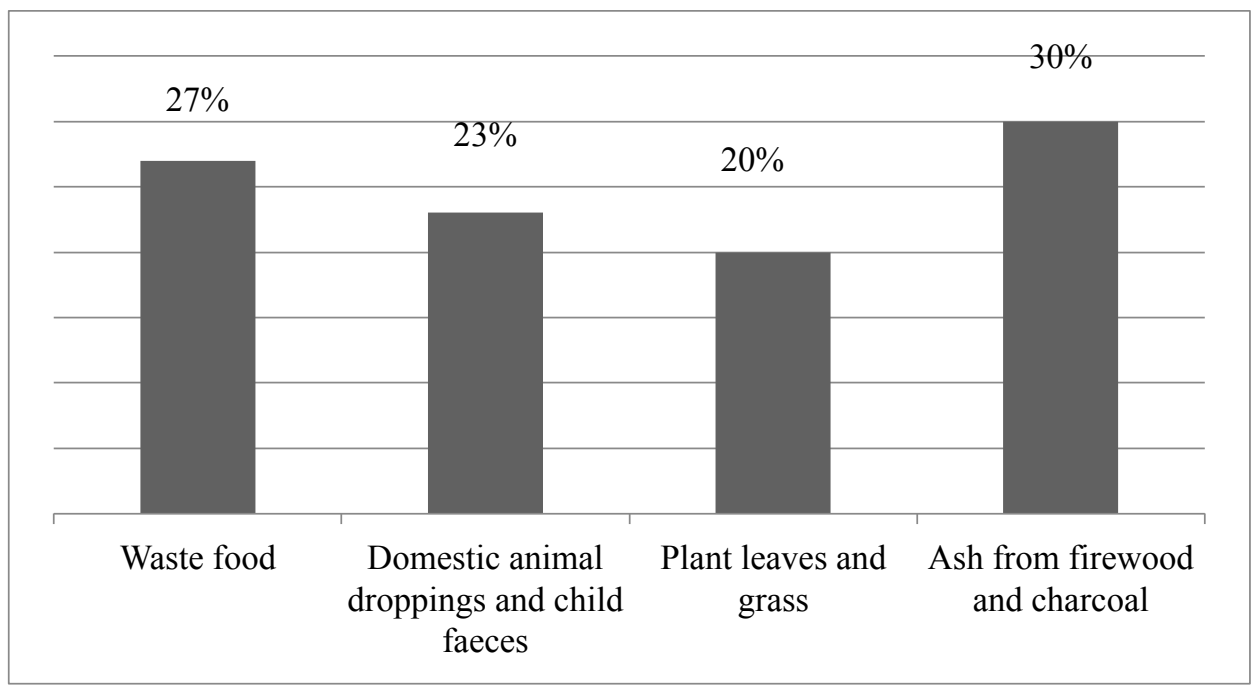

Figure 5: Domestically recyclable household solid waste

Source: Field data, 2015

Officials of the District Water and Sanitation Team and Environmental Health Department, also revealed that scrap metal collectors sometimes purchase metallic waste from households. Zoomlion Ghana Ltd. engages scavengers in waste sorting at landfill and open dump sites. Households are also encouraged to sort out some specified wastes. The wastes are classified into plastics, foods, metals and glass for the purpose of recycling (See also Kale-Dery, 2014). These are then valued and paid for by the company, for use in the Zoomlion Sorting and Compost Plant at the Adjen Kotoku community along the Accra-Nsawam road. The plant produces quality compost for agricultural purposes (Zoomlion Ghana Ltd., 2015). Unfortunately this opportunity is not available to the residents of Nadowli, because the compost plant receives adequate sorted wastes from its neighbouring settlements based on its existing capacity. The absence of public sector intervention in the sphere of waste recycling further perpetuates the increasing volumes of potentially recyclable waste. Thus, even though waste recycling is practised, it is limited in terms of coverage and stakeholder commitment.

\section{Waste Reuse}

Table 4 shows how respondents described reuse of durable materials. The responses include the identification of materials that were supposed to have been waste not within the community or Ghana as a whole, but imported from other countries. Examples are used clothing, shoes and cars. They believed that buying such foreign used products helps to manage solid waste in the advanced countries rather than the local area. However, some household members give out their unwanted clothing and shoes to 
other family members and friends for reuse. This prevents them from entering into the landfill as waste (See also Reuse Development Organisation, 2014).

It was revealed that when durable products such as wooden furniture and electrical appliances including television sets, radios and refrigerators break-down, they could be repaired, or their useful parts removed to refurbish similar products in better conditions to renew their usefulness. Others also explained that parts of local farm tools such as hoe blades, as well as local kitchen knives are produced from the reuse of damaged metallic body parts of motor vehicles by local blacksmiths. Some households also use old clay pots and open plastic and metal containers for growing potted plants for home decoration.

Table 4: Durable household solid waste for reuse

\begin{tabular}{|l|l|}
\hline Type of waste & Method of reuse \\
\hline $\begin{array}{l}\text { Unwanted textile and leather products, such as } \\
\text { clothing, shoes, belts, hand bags }\end{array}$ & $\begin{array}{l}\text { Buying as second-hand products or given out } \\
\text { as gifts. }\end{array}$ \\
\hline $\begin{array}{l}\text { Broken-down or outmoded furniture, electrical } \\
\text { (e.g. radio and TV sets and refrigerators) and } \\
\text { mechanical appliances (lorries and motor bicycles) }\end{array}$ & $\begin{array}{l}\text { Buying as second-hand products, repairing, } \\
\text { refurbishing for reuse by original owners, } \\
\text { and finding alternative uses of the damaged } \\
\text { products (e.g. cutting lorry body parts to } \\
\text { make hoe blades and kitchen knives) by } \\
\text { blacksmiths. }\end{array}$ \\
\hline $\begin{array}{l}\text { Scrap concrete, wooden, glass and iron roofing } \\
\text { sheets from collapsed or abandoned old buildings } \\
\text { and other constructional works }\end{array}$ & $\begin{array}{l}\text { Retrieval of useful materials for reuse in other } \\
\text { buildings, reconstruction and renovation of } \\
\text { old buildings, or the use of the scrap materials } \\
\text { for other purposes. }\end{array}$ \\
\hline $\begin{array}{l}\text { Scrap clay pots, bottles, plastic and metal } \\
\text { containers }\end{array}$ & $\begin{array}{l}\text { Old pots and plastic containers are used for } \\
\text { growing potted plants for home decoration; } \\
\text { bottles are reused for storing water in } \\
\text { refrigerators. }\end{array}$ \\
\hline
\end{tabular}

Source: Field data, 2015

On the part of the public and private sectors, the official of the District Water and Sanitation Team stated their roles in community education for reuse of durable products. He added that some bottled product companies, as part of their environmental management plans, implement a buy-back strategy, by encouraging school children and scavengers to sort their product bottles for refurbishment and reuse. However, this does not happen in Nadowli.

Despite the adequate account of waste reuse in the community, the categories of waste identified above were seen near homes, the surroundings, open dump sites and the 
landfill sites by direct observation. Also, inadequate technical skills for repair services for some repairable appliances result in their being thrown out as waste. These increase demand for new products and the cycle repeats itself, thus, reducing the positive effects of waste reuse.

\section{Waste Reduction}

Officials of Zoomlion and District Water and Sanitation Team in Nadowli, disclosed that waste reduction is more of a household method of waste management, since it is behavioural. They added that their organisations, with the support of the District Assembly, District Environmental Health Department, donor agencies such as UNICEF and the civil society organisations such as MAYFORD Foundation and CARE International, organise public educational programmes for residents regarding good sanitary behaviour.

The findings in Table 5 are consistent with the description of waste reduction by Dickinson and Snow (2001) and the United States Environmental Protection Agency (2012), that waste reduction is an eliminatory decision making process by households, regarding their consumption choices. They also consider waste reduction to be contributory to natural resource conservation, by reducing the frequency of exploitation of natural resources to produce the goods. This in addition to waste reuse, recycle and energy recovery, ensure environmental sustainability, because they reduce pressure on resource use and so guarantee the needs of present and future generations (Dickinson \& Snow, 2001).

Despite the knowledge and practice of waste reduction, most households go to shop with empty hands and return home with lots of polythene packages and paper wrappers, which are less durable for reuse. However, being the second most preferred option on the hierarchy of waste management, the existing situation in Nadowli is a good potential for further improvement of the sanitation situation. 
Table 5: Waste reduction methods

\begin{tabular}{|l|l|}
\hline Type of waste & Method of reduction \\
\hline Yard waste including paper, sachets. & $\begin{array}{l}\text { Some women use durable shopping baskets in the } \\
\text { market to avoid too much packaging }\end{array}$ \\
\hline Food waste & $\begin{array}{l}\text { Preservation of leftover and stored foods to avoid } \\
\text { decay }\end{array}$ \\
\hline Animal droppings & Practice of intensive system \\
\hline Scrap concrete, metals, glass and wood wastes & $\begin{array}{l}\text { Use of quality and durable materials in building and } \\
\text { constructional works for long lasting residential } \\
\text { structures }\end{array}$ \\
\hline $\begin{array}{l}\text { Worn-out metallic, plastic, bottle, clayey and } \\
\text { wooden utensils, appliances and leather products }\end{array}$ & $\begin{array}{l}\text { Maintenance, repair and reuse of existing metallic, } \\
\text { clayey and wooden utensils and bottles. }\end{array}$ \\
\hline Textile and leather wastes & Old clothing used for wrapping babies \\
\hline
\end{tabular}

Source: Field data, 2015

\section{Waste Avoidance}

Waste avoidance is the most preferred waste management practise as it appears at the top of the hierarchy of waste management methods in the conceptual framework. Figure 6 shows household respondents' identification of the practices that could avoid waste in the community. A majority of $45 \%$ of the respondents agreed that when they avoid buying items with disposable components, such as packaged food, drink, clothing and other new products the associated household solid waste would be avoided. Avoidance of using single serving containers ranked next with $41 \%$. For example small and less durable polythene bags disposable after first use could be avoided. Yet these two are the most observable solid wastes, not only in Nadowli, but the country at large.

Since the undesirable aspect of waste is its tendency to pollute the environment, $8 \%$ of the respondents saw the need to avoid such products. Thus, disposal of used injection syringes and contraceptive sheath are potentially dangerous to other people's lives through risk of infection upon contact. Medical practices that prevent these from exposure to the environment or entering landfills are the best options.

Also, 6\% of the respondents saw the practices of waste reduction, recycle and reuse as contributing to waste avoidance. Recognising that waste avoidance is behavioural, formal sector institutional influences take the forms of educational campaigns and sanctioning for non-compliance to bye-laws. The latter is usually through the work of sanitary inspectors from the Environmental Health Department during house-to-house inspection. However, while most of the respondents knew about the best methods to avoid waste, adherence to habits of reducing choices and consumption of waste generating products were problematic. Additionally, inadequate staffs for sanitary 
inspection, negative impact of illiteracy and low coverage of campaign programmes, limit the effectiveness of waste avoidance.

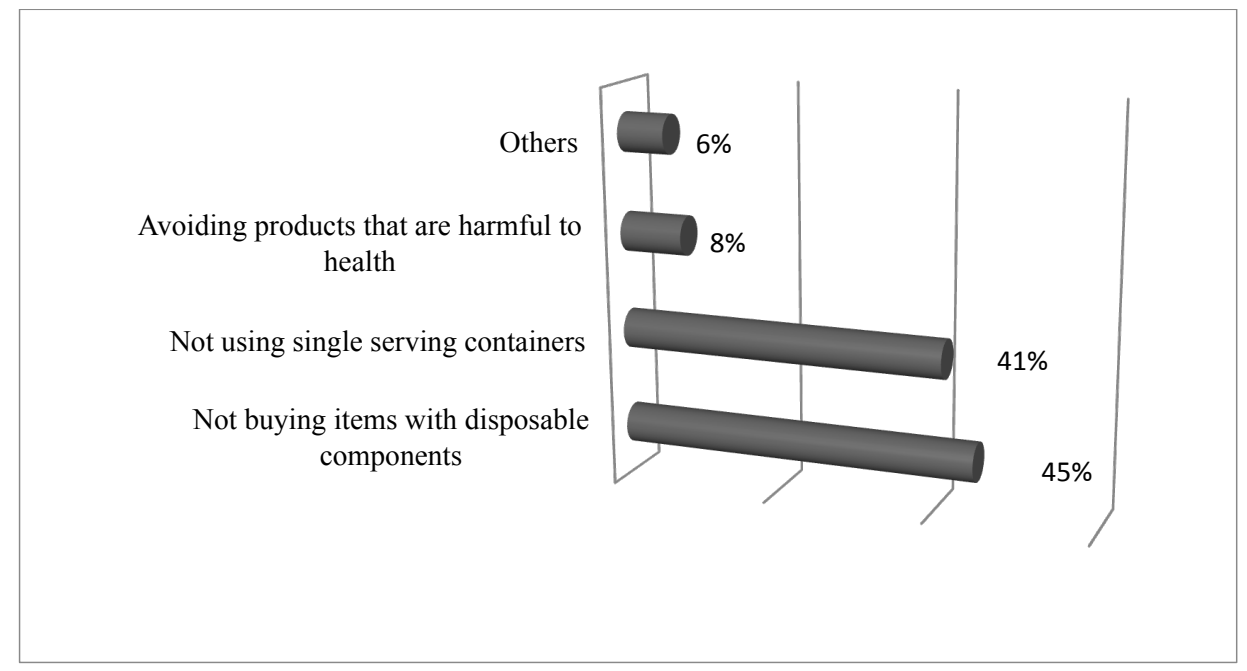

Figure 6: Methods of waste avoidance

According to the official of Nadowli Hospital, the hospital educates the public through posters on hospital walls, as well as direct talks to women on pre-natal and post-natal attendance, about good sanitation practices. However, Table 6 shows the prevalence of diseases associated with poor sanitation, implying ineffective waste management practices (UN Water, 2008). The diseases include cholera, diarrhea, typhoid fever, malaria and tetanus.

Table 6: Diseases related to poor sanitation

\begin{tabular}{|l|l|l|l|}
\hline Disease & Causal organism & $\begin{array}{l}\text { Associated poor sanitary } \\
\text { condition }\end{array}$ & Level of prevalence \\
\hline Cholera & vibrio cholera & $\begin{array}{l}\text { Contaminated food } \\
\text { and water due to dirty } \\
\text { environment }\end{array}$ & Low \\
\hline Diarrhoea & Cryptosporidium bacterium & $\begin{array}{l}\text { Contaminated food } \\
\text { and water due to dirty } \\
\text { environment }\end{array}$ & High \\
\hline Typhoid fever & Salmonella typhi bacterium & $\begin{array}{l}\text { Contaminated food } \\
\text { and water due to dirty } \\
\text { environment }\end{array}$ & Moderate \\
\hline Malaria & $\begin{array}{l}\text { Plasmodium through female } \\
\text { anopheles mosquito bite }\end{array}$ & $\begin{array}{l}\text { Landfills, dump sites and } \\
\text { stagnant water }\end{array}$ & High \\
\hline Tetanus & $\begin{array}{l}\text { Clostridium tetani bacterium } \\
\text { Street dirt and scrap rusty } \\
\text { metals }\end{array}$ & Moderate \\
\hline
\end{tabular}

Source: Interview with hospital officials, 2015 
This aids a conclusion that gaps exist between theory and practise in household waste management in Nadowli.

\section{Outcomes}

It is believed that waste avoidance prevents solid waste from being generated, while waste reduction, reuse, recycling and recovery do not only prevent environmental pollution, but also lead to disease prevention, environmental resource conservation and sustainability (as shown in the conceptual framework). The case of Nadowli shows that lack of adequate staff, funding, illiteracy, poverty and inadequate campaign strategies affect the effective implementation of the various methods. Deductively, the persistence of some diseases associated with poor sanitation in Nadowli, means efforts of the stakeholders in waste management have not been effective, since pollution still persists, evidenced by the incidences of diseases. Furthermore, the identified limitations in waste reduction, reuse, recycling and recovery imply that environmental sustainability is threatened, since the expected reduction in environmental resource use as discussed in the conceptual issues cannot be effectively attained (Kinhal, 2017).

\section{Conclusions}

This study has demonstrated that in practice, the methods of the hierarchy of waste management model could not be applied without the roles of identified stakeholders in relation to the types and sources of waste. Furthermore, the conceptual understanding of the methods of waste management enabled the measurement of the appropriateness of the roles of the stakeholders regarding what they actually practice. For instance, waste avoidance, which is the most important method in the hierarchy, is of little priority in the roles of public-private sector stakeholders. It is revealed that while the aim of waste reduction, reuse, recycle and recovery is to reduce the amount of solid waste that actually ends in the landfill, the major practice by the public-private sector and households is about the collection and disposal of the waste, which is the least important method in the hierarchy of waste management model.

Additionally, while the public sector, through its ministries and departments has the responsibility of providing services and ensuring effectiveness in waste management to the public, the major player was rather the private sector Zoomlion Ghana Ltd., which was itself constrained by inadequate funding by the public sector. These created a situation where the ability to pay is the only means by which households can access waste management services.

Finally, although there are different sources and types of waste, the existing solid waste management practices by the public-private sector and the infrastructural setup are 
not differentiated according to the types. Findings were largely about what households themselves do in accordance to the waste management hierarchy. Thus, the roles of households, which were identified as being the least important stakeholders in waste management in the conceptual framework were rather the most dominant.

As a result of the ineffective roles of the stakeholders in various methods of waste management, the prevention of pollution has not been successful, evidenced by incidences of diseases due to poor sanitation. For the same reason, environmental resource conservation and sustainability are also in jeopardy. It is recommended that adequate identification of the types of waste and effective execution of stakeholder roles, especially those of the Ministry of Local Government and Rural Development in terms of funding, and the Ministry of Environment, Science and Technology in line with the appropriate methods of managing each type, would make the effects of waste avoidance, reduction, reuse, recycle, recovery and disposal as the key elements of the waste management hierarchy theory more realistic.

\section{References}

Adank, M. and Tuffuor, B. (2013). Management models for the provision of small town and peri-urban water services in Ghana. Accra: Resource Centre Network.

Ali, A., Wang, W. and Chauhdry. N. (2016). Application of life cycle assessment for hospital solid waste management: A case study. Journal of the Air and Waste Management Association, 66 (10), pp. 1012-1018.

Anokye, N.A. (2013). Stakeholder participation in water resources management: the Case of Densu Basin in Ghana. A doctoral thesis. Amsterdam: University of Amsterdam.

Baud, I., Post, J. and Furedy, C. (2004). Solid waste management and recycling: actors, partnerships and policies in Hyderabad, India, and Nairobi, Kenya. New York: Kluwer Academic Publishers.

Chukwudi, N.G.M. and Oluwafemi, 0.0. (2014). Survey of waste-bins and collection methodology in households of the federal capital city, Abuja, Nigeria. International Journal of Scientific \& Technology Research, 3(9), pp. 183-196.

Civil Society Organisations Communiqué. (2011). Second annual civil society review of the natural resources and environment sector in Ghana:-June 2011 (online). Available at: http://www.modernghana.com/news/340942/1/second-annual-civil-societyreview-of-the-natural-.html. Accessed 15th June, 2015.

Community Water and Sanitation Agency (CWSA) (2004). Strategic Investment Plan2005 2015. Accra: CWSA. 
Dickinson, J. and Snow, w.K. (2001). The end of waste: zero waste by 2020. Albany: Zero Waste New Zealand Trust.

Ewijk van, S. and Stegemann, J.A. (2014). Limitations of the waste hierarchy for achieving absolute reductions in material throughput. Journal of Cleaner Production, (2014), pp. 1-7.

Getis, A., Getis, J. and Fellman, J.D. (2006). Introduction to Geography. New York: Mc Graw Hill.

Ghana Statistical Service (GSS) (2014). District analytical report: Nadowli District. Accra: GSS.

Ghana Statistical Service (2014). Ghana living standards survey round 6. Accra: GSS.

Government of Ghana (2010). National environmental sanitation strategy and action plan: Materials in transition. Accra: Ministry of Local Government and Rural Development.

Griffin, F. (2006). Pollution prevention and waste management issues and activities in the Pacific Islands Region. Port Moresby: University of Papua New Guinea.

Janmaimoo, P. (2017). Application of protection motivation theory to investigate sustainable waste management behaviors. Sustainability, 9 (1079), pp. 1-16.

Kale-Dery, S. (2014). A step towards Accra's waste menace. Graphic (online). Available at: http://graphic.com.gh/features/features/17124-a-step-towards-solving-accra-swaste-menace.h. Accessed 6th February, 2014.

Kane, E. (1995). Seeing for yourself: research handbook for girls in Africa.Washington:

\section{The International Bank for Reconstruction and Development/The World Bank.}

Kendie, S. B. (1999). Do attitudes matter? Waste disposal and wetland degradation in the Cape Coast Municipality of Ghana. Development and Project Planning Centre Discussion Paper Series 2, No.21 University of Bradford, England.

Kinhal, V. (2017). What impact does recycling have on the environment (online). Available at: http://greenliving.lovetoknow.com/How_Does_Recycling_Affect_ the_Environment. Accessed 8th August, 2017.

Komives, K., Akanbang, B., Thorsten, R., Tuffuor, B., Wakeman, W., Larbi, E., Bakalianand, A. and D. Whittington. (2008). Post-construction support and the sustainability of rural water projects in Ghana. Paper presented at the 33rd WEDC International Conference - Access to Sanitation and Safe Water: Global Partnerships and Local Actions (Accra), p. 4. 
Kumasi Metropolitan Assembly (2015).Waste management (online). Available at: http:// www.kma.gov.gh $/ \mathrm{kma} /$ ?waste-management\&page=5312. Accessed 13th June, 2015 .

Ministry of Environment, Science and Technology (2012). Programme based budgetpilot. Accra: MEST.

Mondal, P. (2015). Twenty important characteristics of urban community (online). Available at: http://www.yourarticlelibrary.com/sociology/20-important-characteristicsof-urban-community-sociology/4873/. Accessed $8^{\text {th }}$ June, 2015.

Nadowli-Kaleo District Assembly (2013). Nadowli District Profile. Nadowli: NadowliKaleo District Assembly.

Nadowli-Kaleo District Assembly (2016). Composite budget of the Nadowli-Kaleo District Assembly for the 2016 fiscal year. Nadowli: Republic of Ghana.

Organic Standards and certification capacity in East Africa (2015). Impacts associated with the uptake of organic. Vignola: International Federation of Organic Agriculture Movements.

Palm, D. (2011). Improved waste management of textiles: project-environmentally improved recycling. Goteborg: Swedish Environmental Research Institute Ltd.

Picket, c. (2010). Improving the waste management hierarchy"the sustainability hierarchy”. Minneapolis: The Sustainability Industry/The Envirobiz Group Inc.

Randell, P. (2012). Beneficial reuse and resource recovery of waste materials: an inventory of Australian over-arching objectives and guiding principles. San Francisco: Randell Environmental Consulting.

Reuse Development Organisation (ReDo) (2014). The benefits of reuse. Baltimore: ReDo.

Snel, M. and Ali, M. (1999). Stakeholder analysis in local solid waste management schemes. London and Louchborough: WELL.

Tonjes, D.J. and Greene, K.L. (2013). Degradable plastics and solid waste management systems. New York: Stony Brook University.

Toxics Action Center (2012). Organizing with residents to clean up and prevent pollution in new England since 1987. Boston: TAC.

United States Environmental Protection Agency (2012). Waste-hazardous, wastewaste minimisation (online). Available at: http://www.epa.gov/waste/hazard/ wastemin/index.htm. Accessed 3oth June, 2015. 
United States Environmental Protection Agency (2014). Wastes - Non-Hazardous Waste Municipal Solid Waste (online). Available at: http://www.epa.gov/waste/ nonhaz/municipal/wte/basic.htm. Accessed 26th June, 2015.

United States Environmental Protection Agency (2014). Energy recovery from waste (online). Available at: http://www.epa.gov/waste/nonhaz/municipal/wte/. Accessed 26th June, 2015.

UN Water (2008). Sanitation is vital for health. Geneva: World Health Organisation.

Van de Klundert, A. and J. Anschiitz (2000). The sustainability of alliances between stakeholders in waste management. Working paper for Urban Waste Expertise Programme (UWEP)/ Collaborative Working Group (CWG) (online). Available at: www.gdrc.org/uem/waste/ISWM.pdf. Accessed June 7, 2015.

Van de Klundert, A. and Anschutz. J. (2001). Integrated sustainable waste managementthe concept. Tools for decision-makers, experiences from urban waste expertise programme (1995-2001). Gouda: WASTE.

Vergara, S.E. and Tchobanoglous, G. (2012). Municipal solid waste and the environment: a global perspective. Annual Review of Environment and Resources 37, pp. 277.

Walker, C., Viaro, A. and Wolf, M. (1999). Partnerships for urban environmental management: the roles of urban authorities, researchers and civil society. Environment and Urbanization, 11 (2), pp. 113-125.

Water-Aid (2005). Assessment of national sanitation policies: Ghana case, final report. Accra: Water-Aid Ghana. Accessed $3{ }^{\text {rd }}$ March, 200 8, p. 19.

World Bank (1999). Decision-making guide to municipal solid waste incineration. Washington DC: World Bank.

Yamane, T. (1967). Statistics: An Introductory Analysis, 2nd Edition. New York: Harper and Row.

Zeng, X., Sun, Q., Huo, B., Wan, H. and Jing, C. (2010). Integrated solid waste management under global warming. The Waste Management Journal, 3 (13), pp. 13-17.

Zoomlion Ghana Ltd. 2015. Zoomlion sorting and compost plant: solution to Ghana's waste disposal problems. Accra: Zoomlion Ghana Ltd. 